\title{
Synthesis and Antimicrobial Evaluation of Some New Pyrazolo[1,5-a]pyrimidine and Pyrazolo[1,5-c]triazine Derivatives Containing Sulfathiazole Moiety
}

\author{
Elsherbiny Hamdy El-Sayed, ${ }^{1, \star}$ Ahmed Ali Fadda ${ }^{2}$ \\ and Ahmed Mohamed El-Saadaney ${ }^{1}$ \\ ${ }^{1}$ Department of Chemistry, Faculty of Science, Port Said University, 42526 Port Said, Egypt, \\ ${ }^{2}$ Department of Chemistry, Faculty of Science, Mansoura University, Mansoura, Egypt, \\ *Corresponding author: E-mail: Saeed201691@yahoo.com \\ Tel.: +201024689767
}

Received: 01-31-2019

\begin{abstract}
A number of important fused heterocyclic systems have been prepared by the reaction of 4-((3,5-diamino- $1 H$-pyrazol-4-yl)-diazenyl)- $N$-(thiazol-2-yl)-benzenesulfonamide with some bifunctional nucleophiles such as ethyl acetoacetate, acetylacetone or arylidenemalonononitrile derivatives to obtain pyrazolo[1,5-a]pyrimidine derivatives. The structures of the newly synthesized compounds were determined based on their IR, ${ }^{1} \mathrm{H}$ and ${ }^{13} \mathrm{C}$ NMR and mass spectroscopic data. Most of the compounds produced showed good antibacterial and antifungal activity.
\end{abstract}

Keywords: Sulfathiazole; benzenesulfonamide; pyrazole; antimicrobial evaluation.

\section{Introduction}

It is known that sulfathiazole derivatives have a decisive new and differentiating application in various areas of chemistry. ${ }^{1-3}$ The pyrazole skeleton is a common core in many pharmaceutically active compounds and is important for a wide range of pharmacological activities including anti-inflammatory, ${ }^{4,5}$ antiviral, ${ }^{6}$ antimicrobial, ${ }^{7}$ antifungal, ${ }^{8,9}$ hypoglycemic, ${ }^{10,11}$ antihyperlipidemic, ${ }^{12}$ cyclooxygenase-2 inhibitors, ${ }^{13} \mathrm{CDK} 2 /$ cyclinA inhibitors, ${ }^{14,15}$ and anti-angiogenic activity. ${ }^{16}$ Furthermore, carbonyl cyanide-phenylhydrazone is an efficient decoupler of oxidative phosphorylation sites in a mitochondrial organism. ${ }^{17}$ In this study, arylhydrazonomalononitrile was prepared and used as a reactive intermediate in the synthesis of various heterocyclic compounds with expected critical biological activity. Therefore, we report here on the synthesis of some new sulfathiazole derivatives to investigate their antimicrobial activity.

\section{Experimental}

All melting points were determined with the electrical melting point device from Gallenkamp and are uncor- rected. Precoated Merck Silica gel plates 60F-254 were used for thin layer chromatography (TLC) and the spots were detected under UV light $(254 \mathrm{~nm})$. The infrared spectra (IR) were recorded with a Mattson 5000 FTIR spectrophotometer ( $\mathrm{KBr}$ plate). The NMR spectra were recorded on Varian Gemini spectrometer at $400 \mathrm{MHz}\left({ }^{1} \mathrm{H}\right.$ NMR) and $100 \mathrm{MHz}\left({ }^{13} \mathrm{C}\right.$ NMR). Deuterated DMSO- $d_{6}$ was used as solvent and tetramethylsilane (TMS) as internal standard. The chemical shifts were measured in $\delta$ ppm relative to the TMS. Mass spectra were determined with a GC-MS QP-100 EX Shimadzu instrument, and elemental analysis was performed with a Perkin-Elmer 2400 elemental analyzer.

Synthesis of $\mathrm{N}-(4-(\mathrm{N}-($ thiazol-2-yl)sulfamoyl)phenyl)carbonohydrazonoyl dicyanide (2)

To a solution of malononitrile $(0.66 \mathrm{~g}, 10 \mathrm{mmol})$ in ethanol $(30 \mathrm{ml})$ 0,5 $\mathrm{g}$ anhydrous sodium acetate was added. The solution was then treated with a solution of diazonium salt of p-aminosulfathiazole (prepared from (2.55 g, $10 \mathrm{mmol}$ p-aminosulfathiazole and the corresponding quantities of hydrochloric acid and sodium nitrite). The reaction mixture was stirred for 1 hour and the resulting 
solid was filtered off, washed with water and recrystallized from ethanol to compound 2. Golden yellow crystals; yield: $90 \%$; $\mathrm{mp} 215-220^{\circ} \mathrm{C}$; IR ( $\left.\mathrm{KBr}\right): v 3234,3188(2 \mathrm{NH})$, 2225 and $2216(2 \mathrm{CN}), 1654(\mathrm{C}=\mathrm{N}) 1565(\mathrm{~N}=\mathrm{N}) \mathrm{cm}^{-1} ;{ }^{1} \mathrm{H}$ NMR $\left(400 \mathrm{MHz}, \mathrm{DMSO}-d_{6}\right): \delta 6.81(\mathrm{~d}, 1 \mathrm{H}, \mathrm{H}-5$, thiazole ring, $J=4.2), 7.21(\mathrm{~d}, 1 \mathrm{H}, \mathrm{H}-4$, thiazole ring, $J=4.2), 7.75$ (d, $2 \mathrm{H}, \mathrm{Ar}-\mathrm{H}, J=8.5), 8.00$ (d, 2H, Ar-H, J=8.5), $11.61(\mathrm{~s}, 1 \mathrm{H}$, $\mathrm{NH}), 12.30\left(\mathrm{~s}, 1 \mathrm{H}, \mathrm{NHSO}_{2}\right) \mathrm{ppm} ;{ }^{13} \mathrm{C}$ NMR $(100 \mathrm{MHz}$, DMSO- $\left.d_{6}\right): \delta 85.6,112.3,114.5,116.8,129.7,132.0,139.6$, 147.9, 171.5 ppm; MS: $m / z(\%) 332\left(\mathrm{M}^{+}, 31.8\right), 257$ (49), 71 (44), 55 (72), 43 (100). Anal. Calcd. for $\mathrm{C}_{12} \mathrm{H}_{8} \mathrm{~N}_{6} \mathrm{O}_{2} \mathrm{~S}_{2}$ (332.36): C, 43.37; H, 2.52; N, $25.29 \%$. Found: C, 43.51; H, $2.63 ; \mathrm{N}, 25.39 \%$.

\section{Synthesis of 4-((3,5-diamino-1H-pyrazol-4-yl)diazenyl)-} $\mathrm{N}$-(thiazol-2-yl)benzenesulfonamide (3)

A mixture of $2(3.32 \mathrm{~g}, 10 \mathrm{mmol})$ and hydrazine hydrate $(0.5 \mathrm{ml}, 10 \mathrm{mmol})$ was added to ethanol $(10 \mathrm{ml})$ under reflux for 3 hours and then cooled to room temperature. The precipitate formed was collected by filtration, dried and recrystallized from a mixture of $\mathrm{DMF} / \mathrm{EtOH}$ (1:1) to obtain compound 3 . Yellow needles crystals; yield: 78\%; mp 235-240 ${ }^{\circ} \mathrm{C}$; IR (KBr): v 3430, 3373, 3337, 3289, $3219\left(2 \mathrm{NH}_{2}\right.$ and $\left.2 \mathrm{NH}\right) \mathrm{cm}^{-1}$; ${ }^{1} \mathrm{H}$ NMR $(400 \mathrm{MHz}, \mathrm{DM}-$ SO- $\left.d_{6}\right): \delta 6.27\left(\mathrm{~s}, 4 \mathrm{H}, 2 \mathrm{NH}_{2}\right), 6.81(\mathrm{~d}, 1 \mathrm{H}, \mathrm{H}-5$, thiazole ring, $J=4.2), 7.21$ (d, $1 \mathrm{H}, \mathrm{H}-4$, thiazole ring, $J=4.2), 7.73$ (d, $2 \mathrm{H}, \mathrm{Ar}-\mathrm{H}, J=8.5), 7.79$ (d, 2H, Ar-H, $J=8.5), 12.64$ (s, $1 \mathrm{H}$, $\left.\mathrm{NHSO}_{2}\right), 12.66(\mathrm{~s}, 1 \mathrm{H}, \mathrm{NH}) \mathrm{ppm} ;{ }^{13} \mathrm{C}$ NMR $(100 \mathrm{MHz}$, DMSO- $\left.d_{6}\right): \delta 74.5,112.4,127.9,129.7,132.0,139.6,137.9$, 151.5, 171.9 ppm; MS: $m / z$ (\%) $364\left(\mathrm{M}^{+}, 0.9\right), 275$ (49) 147 (10), 97(34), 57 (81); Anal. Calcd for $\mathrm{C}_{12} \mathrm{H}_{12} \mathrm{~N}_{8} \mathrm{O}_{2} \mathrm{~S}_{2}$ (364.40): C, 66.49; H, 4.82; N, 24.67\%. Found: C, 66.43; H, $4.90 ; \mathrm{N}, 24.70 \%$.

General procedure for the reaction of 3,5-aminopyrazole 3 with ethylacetoacetate and 1,3 dicarbonyl compound (acetyl aceton) toward formation of compounds 5 and 6

To a solution of compound $3(0.3 \mathrm{~g}, 1 \mathrm{mmol})$ in glacial acetic acid ( $25 \mathrm{ml})$ the corresponding 1,3-dicarbonyl compound such as ethyl acetoacetate and acetylacetone $(1 \mathrm{mmol})$ was added. The reaction mixture was refluxed for 3 hours under reflux in a sand bath and then poured onto crushed ice. Shaped precipitate was collected by filtration, washed with ethanol, dried and recrystallised from a mixture of DMF/EtOH (1:1) to compounds 5 and $\mathbf{6}$ respectively.

4-((2-Amino-7-methyl-5-oxo-4,5-dihydropyrazolo[1,5-a] pyrimidin-3-yl)diazenyl)- $\mathrm{N}$-(thiazol-2-yl)benzenesulfonamide (5)

Orange crystals; yield: $75 \%$; mp $230-235^{\circ} \mathrm{C}$; IR (KBr): v 3444-3380 $\left(\mathrm{NH}_{2}\right.$ and $\left.\mathrm{NH}\right), 1661(\mathrm{CO}) \mathrm{cm}^{-1} ;{ }^{1} \mathrm{H}$ $\mathrm{NMR}\left(400 \mathrm{MHz}, \mathrm{DMSO}-d_{6}\right): \delta 2.01\left(\mathrm{~s}, 3 \mathrm{H}, \mathrm{CH}_{3}\right), 6.27(\mathrm{~s}$, $\left.2 \mathrm{H}, \mathrm{NH}_{2}\right), 6.81(\mathrm{~d}, 1 \mathrm{H}, \mathrm{H}-5$, thiazole ring, $J=4.2), 7.21(\mathrm{~d}$, $1 \mathrm{H}, \mathrm{H}-4$, thiazole ring, $J=4.2), 7.26(\mathrm{~s}, 1 \mathrm{H}$, pyrimidine ring), $7.73(\mathrm{~d}, 2 \mathrm{H}, \mathrm{Ar}-\mathrm{H}, J=8.5), 7.79(\mathrm{~d}, 2 \mathrm{H}, \mathrm{Ar}-\mathrm{H}, J=8.5)$,
11.46 (s, 1H, NHCO), 12.64 (s, $1 \mathrm{H}, \mathrm{NHSO}_{2}$ ) ppm; ${ }^{13} \mathrm{C}$ NMR (100 MHz, DMSO- $d_{6}$ ): $\delta 22.2,76.9,104.3,112.2$, $127.4,129.2,131.9,137.1,139.8,146.8,147.9,161.3,171.8$ ppm; MS: $m / z(\%) 430\left(\mathrm{M}^{+}, 1.0\right), 139$ (28), 110 (19), 82 (29), 63 (40), 43 (100); Anal.Calcd for $\mathrm{C}_{16} \mathrm{H}_{14} \mathrm{~N}_{8} \mathrm{O}_{3} \mathrm{~S}_{2}$ (430.46): C, 44.64; H, 3.28; N, 26.03\%; Found: C, 44.73; H, $3.32 ; \mathrm{N}, 26.08 \%$.

4-((2-Amino-5,7-dimethylpyrazolo[1,5-a]pyrimidin3-yl)diazenyl)- $\mathrm{N}$-(thiazol-2-yl) benzenesulfonamide (6)

Brown powder; yield: $80 \%$; mp $225-230{ }^{\circ} \mathrm{C}$; IR $(\mathrm{KBr}): v 3437-3394\left(\mathrm{NH}_{2}\right.$ and $\left.\mathrm{NH}\right), 1560(\mathrm{~N}=\mathrm{N}) \mathrm{cm}^{-1} ;{ }^{1} \mathrm{H}$ NMR (400 MHz, DMSO- $\left.d_{6}\right): \delta 2.08\left(\mathrm{~s}, 3 \mathrm{H}, \mathrm{CH}_{3}\right), 2.24(\mathrm{~s}$, $\left.3 \mathrm{H}, \mathrm{CH}_{3}\right), 5.74\left(\mathrm{~s}, 2 \mathrm{H}, \mathrm{NH}_{2}\right), 6.81(\mathrm{~d}, 1 \mathrm{H}, \mathrm{H}-5$, thiazole ring, $J=4.2), 7.08(\mathrm{~s}, 1 \mathrm{H}$, pyrimidine ring), $7.21(\mathrm{~d}, 1 \mathrm{H}$, $\mathrm{H}-4$, thiazole ring, $J=4.2), 7.73(\mathrm{~d}, 2 \mathrm{H}, \mathrm{Ar}-\mathrm{H}, J=8.5), 7.79$ (d, $2 \mathrm{H}, \mathrm{Ar}-\mathrm{H}, J=8.5), 12.67$ (s, $1 \mathrm{H}, \mathrm{NHSO}_{2}$ ) ppm; ${ }^{13} \mathrm{C}$ NMR $\left(100 \mathrm{MHz}, \mathrm{DMSO}-d_{6}\right): \delta 17.7,24.5,87.8,108.9,112.3$, 127.5, 129.4, 131.6, $137.7139 .8,145.8,152.8,164.9,171.9$ ppm; MS: $m / z$ (\%) $428\left(\mathrm{M}^{+}, 7.0\right), 395$ (28), 369 (17), 313 (22), 201 (50), 183 (38), 130 (68), 92 (100). Anal. Calcd for $\mathrm{C}_{17} \mathrm{H}_{16} \mathrm{~N}_{8} \mathrm{O}_{2} \mathrm{~S}_{2}$ (428.49): C, 47.65; H, 3.76; N, 26.15\%; Found: C, 47.74, H, 3.79, N, 26.20\%.

General procedure for the reaction of 3,5-amino pyrazole (3) with 2-(4-chloro and 4-nitro benzylidene)malononitrile:

To a solution of compound $3(0.3 \mathrm{~g}, 1 \mathrm{mmol})$ in ethanol $(25 \mathrm{ml})$ the corresponding arylidene was added, namely 2-(4-chlorobenzylidene)malononitrile $(0.189 \mathrm{mg}$, $1 \mathrm{mmol})$ and 2-(4-nitrobenzylidene)malononitrile $(0.2 \mathrm{~g}$, $1 \mathrm{mmol}$ ) containing a catalytic amount of pipridine. The reaction mixture was refluxed for 3 hours to obtain compounds $\mathbf{7}$ and $\mathbf{8}$, respectively.

4-((2,5-Diamino-7-(4-chlorophenyl)-6-cyanopyrazolo [1,5-a]pyrimidin-3-yl)diazenyl)- $N$-(thiazol-2-yl)benzenesulfonamide (7)

Brown powder; yield: $81 \%$; mp $240-245{ }^{\circ} \mathrm{C}$; IR $(\mathrm{KBr}): v$ 3435-3300, 2191 (for $2 \mathrm{NH}_{2}, \mathrm{NH}$ and $\mathrm{CN}$ functional groups) $\mathrm{cm}^{-1} ;{ }^{1} \mathrm{H}$ NMR $\left(400 \mathrm{MHz}, \mathrm{DMSO}-d_{6}\right): \delta$ $6.28\left(\mathrm{~s}, 2 \mathrm{H}, \mathrm{NH}_{2}\right), 6.81(\mathrm{~d}, 1 \mathrm{H}, \mathrm{H}-5$, thiazole ring, $J=4.2)$, $7.21(\mathrm{~d}, 1 \mathrm{H}, \mathrm{H}-4$, thiazole ring, $J=4.2), 7.54\left(\mathrm{~s}, 2 \mathrm{H}, \mathrm{NH}_{2}\right)$, $7.56(\mathrm{~d}, 2 \mathrm{H}, \mathrm{Ar}-\mathrm{H}), 7.73$ (d, 2H, Ar- $\mathrm{H}, J=8.5), 7.79$ (d, $2 \mathrm{H}$, Ar-H, J=8.5), 7.98 (d, 2H, Ar-H), 12.64 (s, $1 \mathrm{H}, \mathrm{NHSO}_{2}$ ) ppm; MS: $m / z(\%) 551\left(\mathrm{M}^{+}, 10\right), 553\left(\mathrm{M}^{+}+2,1\right), 386(28)$, 280 (35), 242 (28), 185 (75), 139 (57), 105 (71), 69 (61), 42 (52); Anal. Calcd for $\mathrm{C}_{22} \mathrm{H}_{15} \mathrm{ClN}_{10} \mathrm{O}_{2} \mathrm{~S}_{2}$ (551.00): C, 47.96; H, 2.74; N, 25.42\%; Found: C, 47.86, H, 2.68, N, 25.34\%.

4-((2,5-Diamino-6-cyano-7-(4-nitrophenyl)pyrazolo [1,5-a]pyrimidin-3-yl)diazenyl)-N-(thiazol-2-yl)benzenesulfonamide (8)

Dark brown powder; yield: $82 \%$; $\mathrm{mp} 265-270{ }^{\circ} \mathrm{C}$; IR $(\mathrm{KBr})$ v 3426-3399, 2212, $1530\left(2 \mathrm{NH}_{2}, \mathrm{NH}, \mathrm{CN}\right.$ and $\left.\mathrm{NO}_{2}\right)$ $\mathrm{cm}^{-1} ;{ }^{1} \mathrm{H}$ NMR (400 MHz, DMSO- $\left.d_{6}\right): \delta 6.28\left(\mathrm{~s}, 2 \mathrm{H}, \mathrm{NH}_{2}\right)$, 
$6.81(\mathrm{~d}, 1 \mathrm{H}, \mathrm{H}-5$, thiazole ring, $J=4.2), 7.21$ (d, $1 \mathrm{H}, \mathrm{H}-4$, thiazole ring, $J=4.2), 7.53\left(\mathrm{~s}, 2 \mathrm{H}, \mathrm{NH}_{2}\right), 7.73$ (d, 2H, Ar-H, $J=8.5), 7.79$ (d, 2H, Ar-H, J=8.5), 7.98 (d, 2H, Ar-H), 8.29 (d, 2H, Ar-H), 12.64 (s, 1H, $\mathrm{NHSO}_{2}$ ) ppm; ${ }^{13} \mathrm{C}$ NMR (100 $\left.\mathrm{MHz}, \mathrm{DMSO}-d_{6}\right): \delta 87.4,88.3,112.8,116.2,124.5,126.3$, $127.4,129.2,131.5,137.3,139.2,140.9,147.1,147.8,152.7$, 165.6, 169.9, 171.8 ppm; MS: $m / z(\%) 561\left(\mathrm{M}^{+}+1,10\right), 331$ (83), 267 (100), 185 (54), 157 (25), 116 (31), 48 (28); Anal. Calcd for $\mathrm{C}_{22} \mathrm{H}_{15} \mathrm{~N}_{11} \mathrm{O}_{4} \mathrm{~S}_{2}$ (561.56): C, 47.06; H, 2.69; N, 27.44\%; Found: C, 47.13, H, 2.71, N, 27.40\%.

Synthesis of 4-((3-amino-5-(3-phenylthioureido)-1Hpyrazol-4-yl)diazenyl)-N-(thiazol-2-yl) benzenesulfonamide (9)

Compound 3 ( $0.3 \mathrm{~g}, 1 \mathrm{mmol})$ was added to a solution of phenyl isothiocyanate $(1 \mathrm{mmol})$ in pyridine $(10 \mathrm{ml})$ and the reaction mixture was refluxed for 3 hours. The mixture was then poured into crushed ice, a few drops of $\mathrm{HCl}$ were added and the resulting solid was filtered and recrystallized from ethanol to obtain compound 9. Brown powder; yield: 76\%; mp $245-250{ }^{\circ} \mathrm{C}$; IR (KBr) v 3444, $3424\left(\mathrm{NH}_{2}\right.$ and $4 \mathrm{NH}), 1644-1561(\mathrm{~N}=\mathrm{N}) ;{ }^{1} \mathrm{H}$ NMR (400 MHz, DMSO- $\left.d_{6}\right): \delta 6.27\left(\mathrm{~s}, 2 \mathrm{H}, \mathrm{NH}_{2}\right), 6.81(\mathrm{~d}, 1 \mathrm{H}, \mathrm{H}-5$, thiazole ring, $J=4.2$ ), 7.21 (d, $1 \mathrm{H}, \mathrm{H}-4$, thiazole ring, $J=4.2$ ), 7.31-7.79 (m, 5H,Ar-H), 7.73 (d, 2H, Ar-H, J=8.5), 7.79 (d, 2H, Ar$\mathrm{H}, J=8.5), 10.7$ (s, 1H, NHC=S), 11.20 (s, 1H, NHC=S), 12.42 ( s, 1H, NH), 12.64 (s, 1H, $\mathrm{NHSO}_{2}$ ) ppm; ${ }^{13} \mathrm{C} \mathrm{NMR}$ $\left(100 \mathrm{MHz}, \mathrm{DMSO}-d_{6}\right): \delta 74.5,112.2,126.7,127.4,128.5$, $129.1,129.8,131.9,137.1,138.6,139.8,151.4,171.8,179.9$ ppm; MS: $m / z$ (\%) $500\left(\mathrm{M}^{+}, 30\right), 394$ (7), 298 (5), 284 (19), 259 (23), 214 (10), 193 (11), 109 (63), 85 (100), 68 (68), 42 (95); Anal. Calcd for $\mathrm{C}_{19} \mathrm{H}_{17} \mathrm{~N}_{9} \mathrm{O}_{2} \mathrm{~S}_{3}$ (499.59): C, 45.68; $\mathrm{H}$, 3.43; N, 25.23\%; Found: C, 45.77, H, 3.49, N, 25.25\%.

\section{General procedure for synthesis of compounds 11-14}

Diazonium salt of $\mathbf{1 0}(10 \mathrm{mmol})$ was added dropwise in an ice-cold solution of malononitrile, 2-cyanoacetohydrazide, $N$-phenylacetamide and 3,5-dimethylphenol (10 $\mathrm{mmol}$ ) in pyridine and stirred for 1 hour. The reaction mixture was then cooled and the resulting solid was collected by filtration and recrystallized from ethanol.

.4-((4,7-Diamino-3-cyanopyrazolo[5,1-c][1,2,4]triazin8-yl)diazenyl)-N-(thiazol-2-yl) benzenesulfonamide (11) Orange crystals; yield: $83 \%$; mp $250-255{ }^{\circ} \mathrm{C}$; IR $(\mathrm{KBr})$ v 3447-3300 (2NH 2 and $\mathrm{NH}), 2227(\mathrm{CN}), 1644-$ $1600(\mathrm{~N}=\mathrm{N}) \mathrm{cm}^{-1}$; ${ }^{1} \mathrm{H}$ NMR (400 MHz, DMSO- $\left.d_{6}\right): \delta 6.27$ (s, $4 \mathrm{H}, 2 \mathrm{NH}_{2}$ ), $6.81(\mathrm{~d}, 1 \mathrm{H}, \mathrm{H}-5$, thiazole ring, $J=4.2), 7.21$ (d, $1 \mathrm{H}, \mathrm{H}-4$, thiazole ring, $J=4.2$ ), 7.73 (d, 2H, Ar- $\mathrm{H}, J=8.5$ ), 7.79 (d, 2H, Ar-H, J=8.5), 12.64 (s, $1 \mathrm{H}, \mathrm{NHSO}_{2}$ ) ppm; ${ }^{13} \mathrm{C}$ NMR (100 MHz, DMSO- $\left.d_{6}\right): \delta 87.8,112.2,113.4,127.4$, 129.2, 131.2, 137.2, 139.8, 147.2, 149.4, 150.2, 152.8, 171.8 ppm; MS: $m / z(\%) 441\left(\mathrm{M}^{+}, 1\right), 396$ (29), 357 (19), 147(17), 125 (23), 97(34), 57 (100), 69 (67), 43 (76); Anal. Calcd for $\mathrm{C}_{15} \mathrm{H}_{11} \mathrm{~N}_{11} \mathrm{O}_{2} \mathrm{~S}_{2}$ (441.45): C, 40.81; H, 2.51; N, 34.90\%; Found: C, 40.89, H, 2.57, N, 34.95\%.
4-(3-Amino-5-((5-amino-3-oxo-3H-pyrazol-4-yl)diazenyl)-1H-pyrazol-4-yl)diazenyl)-N-(thiazol-2-yl)benzenesulfonamide (12)

Orange powder; yield: $85 \%$; $\mathrm{mp} 250-255^{\circ} \mathrm{C}$; IR (KBr): $v$ 3417-3311 $\left(2 \mathrm{NH}_{2}\right.$ and $\left.2 \mathrm{NH}\right), 1678(\mathrm{CO}), 1565(\mathrm{~N}=\mathrm{N})$ $\mathrm{cm}^{-1}$; ${ }^{1} \mathrm{H}$ NMR (400 MHz, DMSO- $\left.d_{6}\right): \delta 6.28\left(\mathrm{~s}, 2 \mathrm{H}, \mathrm{NH}_{2}\right.$ ), $6.56\left(\mathrm{~s}, 2 \mathrm{H}, \mathrm{NH}_{2}\right), 6.81(\mathrm{~d}, 1 \mathrm{H}, \mathrm{H}-5$, thiazole ring, $J=4.2)$, 7.21 (d, 1H, H-4, thiazole ring, $J=4.2$ ), 7.73 (d, 2H, Ar-H, $J=8.5$ ), 7.79 (d, 2H, Ar-H, J=8.5), 12.64 (s, 1H, $\mathrm{NHSO}_{2}$ ), 13.26 (s, $1 \mathrm{H} \mathrm{NH}$ pyrazole ring) ppm; ${ }^{13} \mathrm{C} \mathrm{NMR} \mathrm{(100} \mathrm{MHz,}$ DMSO- $\left.d_{6}\right): \delta 87.8,112.2,118.4,127.4,129.2,131.2,137.2$, $139.8,145.6,152.7,160.3,167.3,171.8$ ppm; MS: $m / z(\%)$ $472\left(\mathrm{M}^{+}, 0.8\right), 397$ (4), 285 (9), 97 (29), 63 (100), 57 (77), 43 (90); Anal. Calcd for $\mathrm{C}_{15} \mathrm{H}_{12} \mathrm{~N}_{12} \mathrm{O}_{3} \mathrm{~S}_{2}$ (472.46): C, 38.13; $\mathrm{H}$, 2.56; N, 35.58\%; Found: C, 38.20, H, 2.64, N, 35.63\%.

\section{2-((3-Amino-4-((4-(N-(thiazol-2-yl)sulfamoyl)phenyl)} diazenyl)-1H-pyrazol-5-yl)diazenyl)-2-cyano-N-phenylacetamide (13)

Red powder; yield: $83 \%$; mp $255-260{ }^{\circ} \mathrm{C}$; IR (KBr): v 3444-3300 ( $\mathrm{NH}_{2}$ and $\left.3 \mathrm{NH}\right), 2220(\mathrm{CN}), 1678(\mathrm{CO})$, $1565(\mathrm{~N}=\mathrm{N}) \mathrm{cm}^{-1} ;{ }^{1} \mathrm{H}$ NMR $\left(400 \mathrm{MHz}, \mathrm{DMSO}-d_{6}\right): \delta 3.97$ (s, 1H, CHCN), 6.27 (s, 2H, NH $\mathrm{NH}_{2}, 6.81(\mathrm{~d}, 1 \mathrm{H}, \mathrm{H}-5$, thiazole ring, $J=4.2), 7.17-7.53(\mathrm{~m}, 5 \mathrm{H}, \mathrm{Ar}-\mathrm{H}), 7.21(\mathrm{~d}, 1 \mathrm{H}$, $\mathrm{H}-4$, thiazole ring, $J=4.2$ ), $7.73(\mathrm{~d}, 2 \mathrm{H}, \mathrm{Ar}-\mathrm{H}, J=8.5), 7.79$ (d, 2H, Ar-H, J=8.5), 10.02 (s,1H, NHCO), 12.64 (s,1H, $\mathrm{NHSO}_{2}$ ), 13.27 (s, $1 \mathrm{H} \mathrm{NH}$ pyrazole ring) ppm; ${ }^{13} \mathrm{C} \mathrm{NMR}$ $\left(100 \mathrm{MHz}, \mathrm{DMSO}-d_{6}\right): \delta 54.5,87.4,112.3,114.9,121.7$, $127.4,128.9,129.4,130.6,131.9,137.5,138.6,139.8,145.7$, 152.8, 168.4, 171.9 ppm; MS: $m / z(\%) 535\left(\mathrm{M}^{+}, 0.8\right), 241$ (6), 215 (7), 160 (40), 94 (24), 45 (100); Anal. Calcd for $\mathrm{C}_{21} \mathrm{H}_{17} \mathrm{~N}_{11} \mathrm{O}_{3} \mathrm{~S}_{2}$ (535.56): C, 47.10; $\mathrm{H}, 3.20 ; \mathrm{N}, 28.77 \%$; Found: C, 47.19, H, 3.22, N, 28.83\%.

4-(3-Amino-5-((4-hydroxy-2,6-dimethylphenyl)diazenyl)-1H-pyrazol-4-yl)diazenyl)-N-(thiazol-2-yl)benzenesulfonamide (14)

Red powder; yield: $78 \%$; mp $245-250^{\circ} \mathrm{C}$; IR (KBr): v $3445,3330\left(\mathrm{NH}_{2}\right.$ and $\left.2 \mathrm{NH}\right), 3300(\mathrm{OH}), 1550-1600(\mathrm{~N}=\mathrm{N})$ $\mathrm{cm}^{-1} ;{ }^{1} \mathrm{H}$ NMR $\left(400 \mathrm{MHz}, \mathrm{DMSO}-d_{6}\right): \delta 2.36(\mathrm{~s}, 6 \mathrm{H}$, $\left.2 \mathrm{CH}_{3}\right), 6.27\left(\mathrm{~s}, 2 \mathrm{H}, \mathrm{NH}_{2}\right), 6.60(\mathrm{~d}, 2 \mathrm{H}$, phenol ring), 6.81 (d, $1 \mathrm{H}, \mathrm{H}-5$, thiazole ring, $J=4.2), 7.21(\mathrm{~d}, 1 \mathrm{H}, \mathrm{H}-4$, thiazole ring, $J=4.2), 7.73$ (d, $2 \mathrm{H}, \mathrm{Ar}-\mathrm{H}, J=8.5), 7.79$ (d, 2H, Ar-H, J=8.5), 9.19 (s, H, OH), 12.64 (s, 1H, $\mathrm{NHSO}_{2}$ ), 13.27 (s, $1 \mathrm{H}, \mathrm{NH}$ pyrazole ring) ppm; ${ }^{13} \mathrm{C} \mathrm{NMR}(100 \mathrm{MHz}$, DMSO- $\left.d_{6}\right): \delta 18.6,87.8,111.8,112.2,119.8,127.4,129.2$, 131.9, 137.1, 138.4, 139.8, 145.7, 152.8, 156.4, 171.8 ppm; MS: $m / z(\%) 497\left(\mathrm{M}^{+}, 0.8\right), 394$ (7), 284 (19), 259 (23), 151 (14), 109 (63), 91 (33), 85 (100), 42 (95); Anal. Calcd for $\mathrm{C}_{20} \mathrm{H}_{19} \mathrm{~N}_{9} \mathrm{O}_{3} \mathrm{~S}_{2}$ (497.55): C, 48.28; $\mathrm{H}, 3.85 ; \mathrm{N}, 25.34 \%$; Found: C, 48.32, H, 3.80, N, 25.33\%.

\section{N-Methyl-N-(4-(N-(thiazol-2-yl)sulfamoyl)phenyl)car- bonohydrazonoyl dicyanide (15) \\ $\mathrm{K}_{2} \mathrm{CO}_{3}(0,137 \mathrm{~g}, 1 \mathrm{mmol})$ was added to a solution of compound $2(0,3 \mathrm{~g}, 1 \mathrm{mmol})$ in ethanol $(25 \mathrm{ml})$ and stirred}


for 1 hour. $\mathrm{CH}_{3} \mathrm{I}(0.14 \mathrm{ml}, 1 \mathrm{mmol})$ was then added and the solution was stirred for 12 hours. The reaction mixture was poured into crushed ice and a few drops of $\mathrm{HCl}$ were added. The resulting solid was filtered off and recrystallized from ethanol to compound 15. Yellow powder; yield: 76\%; mp $240-245^{\circ} \mathrm{C}$; IR (KBr): v $3300(\mathrm{NH}), 2232(2 \mathrm{CN})$, 1565-1600 $(\mathrm{N}=\mathrm{N}), 1601(\mathrm{C}=\mathrm{N}) \mathrm{cm}^{-1} ;{ }^{1} \mathrm{H}$ NMR $(400 \mathrm{MHz}$, DMSO- $\left.d_{6}\right): \delta 3.35\left(\mathrm{~s}, 3 \mathrm{H}, \mathrm{CH}_{3}\right), 6.81(\mathrm{~d}, 1 \mathrm{H}, \mathrm{H}-5$, thiazole ring, $J=4.2), 7.21(\mathrm{~d}, 1 \mathrm{H}, \mathrm{H}-4$, thiazole ring, $J=4.2), 7.73(\mathrm{~d}$, $2 \mathrm{H}, \mathrm{Ar}-\mathrm{H}, J=8.5$ ), 7.79 (d, 2H, Ar-H, J=8.5), 12.45 (s, $1 \mathrm{H}$, $\left.\mathrm{NHSO}_{2}\right) \mathrm{ppm} ;{ }^{13} \mathrm{C}$ NMR $\left(100 \mathrm{MHz}, \mathrm{DMSO}-d_{6}\right): \delta 34.4$, 84.6, 112.5, 127.6, 128.8, 130.1, 137.2, 147.2, 171.8 ppm; MS: $m / z(\%) 346\left(\mathrm{M}^{+}, 3.3\right), 332$ (14), 283 (11), $267(8), 200$ (10), 191 (18), 156 (42), 93 (100), 80 (34); Anal. Calcd for $\mathrm{C}_{13} \mathrm{H}_{10} \mathrm{~N}_{6} \mathrm{O}_{2} \mathrm{~S}_{2}$ (346.38): C, 45.08; $\mathrm{H}, 2.91 ; \mathrm{N}, 24.26 \%$; Found: C, 45.09, H, 2.95, N, 24.31\%.

\section{2-Amino-2-hydrazineylidene- $\mathrm{N}$-methyl- $\mathrm{N}-(4-(\mathrm{N}-($ thi- azol-2-yl)sulfamoyl)phenyl) acetohydrazonoyl cyanide (16)}

Hydrazine hydrate $(0,05 \mathrm{ml}, 1 \mathrm{mmol})$ was added to a solution of compound $\mathbf{1 5}(0.3 \mathrm{~g}, 1 \mathrm{mmol})$ in ethanol (25 $\mathrm{ml}$ ) and the reaction mixture was refluxed for 4 hours. After cooling, the reaction mixture was poured into ice water, the precipitate was collected, filtered, dried and recrystallized from EtOH/DMF to obtain compound 16. Orange powder; yield: $77 \%$; mp $255-260{ }^{\circ} \mathrm{C}$; IR (KBr): $v$ 3443, $3410\left(2 \mathrm{NH}_{2}\right), 3333(\mathrm{NH}), 2215(\mathrm{CN}) \mathrm{cm}^{-1} ;{ }^{1} \mathrm{H}$ NMR $(400$ $\left.\mathrm{mHz}, \mathrm{DMSO}-d_{6}\right): \delta 3.34\left(\mathrm{~s}, 3 \mathrm{H}, \mathrm{CH}_{3}\right), 5.80\left(\mathrm{~s}, 2 \mathrm{H}, \mathrm{NH}_{2}\right)$, $6.54\left(\mathrm{~s}, 2 \mathrm{H}, \mathrm{NH}_{2}\right), 6.81(\mathrm{~d}, 1 \mathrm{H}, \mathrm{H}-5$, thiazole ring, $J=4.2)$, $7.21(\mathrm{~d}, 1 \mathrm{H}, \mathrm{H}-4$, thiazole ring, $J=4.2), 7.73(\mathrm{~d}, 2 \mathrm{H}, \mathrm{Ar}-\mathrm{H}$, $J=8.5), 7.79$ (d, 2H, Ar-H, J=8.5), $12.46\left(\mathrm{~s}, 1 \mathrm{H}, \mathrm{NHSO}_{2}\right)$ ppm; ${ }^{13} \mathrm{C}$ NMR $\left(100 \mathrm{MHz}\right.$, DMSO- $\left.d_{6}\right): \delta 36.8,108.6,112.2$, 114.8, 115.2, 129.3, 130.2, 137.3, 147.4, 152.9, 171.8; MS: $\mathrm{m} / z(\%) 378.14\left(\mathrm{M}^{+}, 8\right), 336$ (31), 314 (32), 275 (31), 257 (80), 152 (59), 110 (53), 83 (100); Anal. Calcd. for $\mathrm{C}_{13} \mathrm{H}-$ ${ }_{14} \mathrm{~N}_{8} \mathrm{O}_{2} \mathrm{~S}_{2}$ (378.43): C, 41.26; H, 3.73; N, 29.61\%; Found: C, 41.28; H, 3.77; N, 29.64\%.

\section{General procedure for the synthesis of $\mathbf{1 7}$ and 18}

Thiourea $(0.076 \mathrm{~g}, 1 \mathrm{mmol})$ and hydroxylamine hydrochloride $(0.07 \mathrm{~g}, 1 \mathrm{mmol})$ containing a catalytic amount of pypridine ( 5 drops) were added to a solution of compound $2(0.3 \mathrm{~g}, 1 \mathrm{mmol})$ in ethanol $(25 \mathrm{ml})$ and returned under reflux for 4 hours. The reaction mixture was poured into ice water and the prepicitate collected, filtered, dried and recrystallized from EtOH with a few drops of DMF, to obtain 17 and 18 respectively.

\section{4-(2-(4,6-Diamino-2-thioxopyrimidin-5(2H)-ylidene) hydrazineyl)- $\mathrm{N}$-(thiazol-2-yl) benzenesulfonamide (17) \\ Brown powder; yield: $68 \%$; mp $255-260{ }^{\circ} \mathrm{C}$; IR (KBr): $v 3434-3400,1325\left(2 \mathrm{NH}_{2}, 2 \mathrm{NH}\right.$ and $\left.\mathrm{C}=\mathrm{S}\right) \mathrm{cm}^{-1} ;{ }^{1} \mathrm{H}$ NMR (400 MHz, DMSO- $\left.d_{6}\right): \delta 6.58\left(\mathrm{~s}, 2 \mathrm{H}, \mathrm{NH}_{2}\right), 6.61(\mathrm{~s}$, $\left.2 \mathrm{H}, \mathrm{NH}_{2}\right), 6.81(\mathrm{~d}, 1 \mathrm{H}, \mathrm{H}-5$, thiazole ring, $J=4.2), 7.21(\mathrm{~d}$, $1 \mathrm{H}, \mathrm{H}-4$, thiazole ring, $J=4.2), 7.73(\mathrm{~d}, 2 \mathrm{H}, \mathrm{Ar}-\mathrm{H}, J=8.5)$,}

$7.79(\mathrm{~d}, 2 \mathrm{H}, \mathrm{Ar}-\mathrm{H}, J=8.5), 12.45\left(\mathrm{~s}, 1 \mathrm{H}, \mathrm{NHSO}_{2}\right), 12.86$ (s, $1 \mathrm{H}, \mathrm{NH}) \mathrm{ppm} ;{ }^{13} \mathrm{C}$ NMR $\left(100 \mathrm{MHz}, \mathrm{DMSO}-d_{6}\right): \delta 112.2$, $116.8,129.1,130.6,137.2,138.3,147.4,162.8,171.8,230.0$ ppm; MS: $m / z$ (\%) $408\left(\mathrm{M}^{+}, 1\right), 397$ (11), 353 (17), 285 (19), 258 (27), 257 (62), 168 (20), 55 (92), 43 (100); Anal. Calcd. for $\mathrm{C}_{13} \mathrm{H}_{12} \mathrm{~N}_{8} \mathrm{O}_{2} \mathrm{~S}_{3}$ (408.47): C, 38.23; $\mathrm{H}, 2.96 ; \mathrm{N}$, 27.43\%; Found: C, 38.28; H, 2.93; N, 27.42\%.

\section{4-(2-(3-Amino-5-iminoisoxazol-4(5H)-ylidene)hydra-} zineyl)-N-(thiazol-2-yl) benzenesulfonamide (18)

Deep orange powder; yield: $73 \%$; mp $245-250{ }^{\circ} \mathrm{C}$; IR (KBr): $v$ 3444-3300, $1633\left(\mathrm{NH}_{2}, 3 \mathrm{NH}\right.$ and $\left.\mathrm{N}=\mathrm{N}\right) \mathrm{cm}^{-1}$; ${ }^{1} \mathrm{H}$ NMR $\left(400 \mathrm{MHz}\right.$, DMSO- $\left.d_{6}\right): \delta 6.62\left(\mathrm{~s}, 2 \mathrm{H}, \mathrm{NH}_{2}\right), 6.81$ (d, $1 \mathrm{H}, \mathrm{H}-5$, thiazole ring, $J=4.2), 7.21(\mathrm{~d}, 1 \mathrm{H}, \mathrm{H}-4$, thiazole ring, $J=4.2), 7.73(\mathrm{~d}, 2 \mathrm{H}, \mathrm{Ar}-\mathrm{H}, J=8.5), 7.79(\mathrm{~d}, 2 \mathrm{H}$, $\mathrm{Ar}-\mathrm{H}, J=8.5), 9.68(\mathrm{~s}, 1 \mathrm{H}, \mathrm{NH}$ isoxazole $), 12.44(\mathrm{~s}, 1 \mathrm{H}$, $\left.\mathrm{NHSO}_{2}\right), 12.87(\mathrm{~s}, 1 \mathrm{H}, \mathrm{NH}) \mathrm{ppm} ;{ }^{13} \mathrm{C}$ NMR $(100 \mathrm{MHz}$, DMSO- $\left.d_{6}\right): \delta 112.3,116.8,129.8,130.2,136.9137 .2,147.4$, $151.8,158.9,171.9 \mathrm{ppm}$; MS: $m / z(\%) 365,\left(\mathrm{M}^{+}, 8\right), 244(9)$, 239 (16), 229 (15), 207 (21), 119 (40), 97 (91), 66 (100); Anal. Calcd. for $\mathrm{C}_{12} \mathrm{H}_{11} \mathrm{~N}_{7} \mathrm{O}_{3} \mathrm{~S}_{2}$ (365.39): C, 39.45; H, 3.03; N, 26.83\%; Found: C, 39.47; H, 3.10; N, 26.86\%.

\section{Antimicrobial studies}

Whatman filter paper disks were prepared with standard size $(5.0 \mathrm{~mm}$ diameter) and stored in $1.0 \mathrm{Oz}$ screw-capped wide holders for sterilization. These bottles were stored in a hot air oven at $150{ }^{\circ} \mathrm{C}$. The disks of sterilized standard filter paper impregnated with a solution of the test compound in DMSO $(1 \mathrm{mg} / \mathrm{mL})$ were then placed on a supplementary agar plate, which was seeded with the appropriate test organism in triplicates. Standard concentrations of $106 \mathrm{CFU} / \mathrm{mL}$ (Colony Forming $\mathrm{U} / \mathrm{mL}$ ) and $104 \mathrm{CFU} / \mathrm{mL}$ were used individually for the antibacterial and antifungal test. Pyrex glass petri dishes $(9 \mathrm{~cm}$ diameter) were used and two disks of filter paper were inoculated in each plate. The test organisms used were B. subtilis and S. aureus as Gram-positive bacteria and E. coli and $P$. aeruginosa as Gram-negative bacteria. They were also tested for their in vitro antifungal potential against fungal strains of F. oxysporum and C. albicans. Chloramphenicol, cephalothin and cycloheximide were used individually as standard antibacterial and antifungal agents. DMSO alone was used as a control at the same concentrations mentioned above and showed no visible change in bacterial growth. The plates were incubated at $37^{\circ} \mathrm{C}$ for 24 hours for bacteria and 48 hours for fungi. Compounds that exhibited significant growth inhibition zones (14 $\mathrm{mm}$ ) using the double serial dilution technique were additionally examined for their minimum inhibitory concentrations (MICs).

\section{Measurement of the minimum inhibition concentration (MIC) \\ The micro-dilution sensitivity tests in Müller-Hin- ton Broth (oxoid) and Sabouraud Liquid Medium (oxoid)}


were used to determine antibacterial and antifungal activity. Stock solutions of the tested compounds, chloramphenicol, cephalothin and cycloheximide were prepared in DMSO at the concentration of $1000 \mathrm{mg} / \mathrm{mL}$. Each stock solution was diluted with standard method broth to make serial twofold dilutions in the range $500-3.125 \mathrm{mg} / \mathrm{mL} .10$ $\mathrm{mL}$ of the broth containing about $106 \mathrm{CFU} / \mathrm{mL}$ of test bacteria were added to each well of the 96-well microtiter plate. The sealed microtiter plates were incubated for 24 hours at $37^{\circ} \mathrm{C}$ for antibacterial activity and for 48 hours at $37^{\circ} \mathrm{C}$ for antifungal activity in a humid chamber. At the end of the incubation period, the values of the minimum inhibitory concentrations (MIC) were recorded as the lowest concentrations of the substance that showed no visible turbidity. Control experiments with DMSO and uninoculated media were performed in parallel with the test compounds under the same conditions. The substance showed no visible turbidity.

\section{Results and Discussion}

The synthetic strategies for obtaining the target compounds are shown in the Schemes 1-6. The main intermediate $\mathrm{N}$-(4-(N-(thiazol-2-yl)sulfamoyl)phenyl)carbonohydrazonoyldicyanide (2) was prepared by diazotization of sulfathiazole, followed by coupling of the resulting diazonium salt with malononitrile.

The structure of compound $\mathbf{2}$ has been confirmed by its elemental and spectroscopic analysis. The IR spectrum of 2 showed absorption bands at 3234, 3188, 2225, 2216, 1654 and $1565 \mathrm{~cm}^{-1}$, corresponding to two $\mathrm{NH}$, two $\mathrm{CN}$, $\mathrm{C}=\mathrm{N}$ and $\mathrm{N}=\mathrm{N}$ groups respectively. The mass spectrum of compound 2 showed a molecular ion peak at $\mathrm{m} / \mathrm{z} 332$ $\left[\mathrm{M}^{+}\right]$, which is consistent with the proposed structure. Recently, we have synthesized new heterocyclic compounds by studying the behavior of malononitrile derivatives towards different reagents. ${ }^{18-22}$

In continuation of this work we investigated the behavior of compound $\mathbf{2}$ towards hydrazine hydrate. The treatment of compound 2 with hydrazine hydrate in boiling ethanol yielded 4 - ((3,5-diamino- $1 H$-pyrazol-4-yl)diazenyl)- $\mathrm{N}$-(thiazol-2-ylbenzenesulfonamide (3). The structure of pyrazole derivative $\mathbf{3}$ was confirmed by its spectroscopic data and elemental analysis. The mass spectrum of compound 3 together with the elemental analysis confirmed the structure 3 . In addition, the IR spectrum of compound 3 showed the absence of an absorption peak for nitrile groups and the appearance of absorption bands at $3430,3373,3337,3289$ and $3219 \mathrm{~cm}^{-1}$ corresponding to two $\mathrm{NH}_{2}$ and two $\mathrm{NH}$ groups, respectively, confirming the formation of pyrazole derivative 3 (Scheme 2).<smiles>Nc1ccc(S(=O)(=O)Nc2nccs2)cc1</smiles><smiles>O=S(=O)(Nc1nccs1)c1ccc(/N=N/Cl)cc1</smiles>

(1)

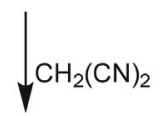<smiles>N#CC(C#N)=NNc1ccc(S(=O)(=O)Nc2nc(C=C3C=CC=C3)cs2)cc1</smiles>

Scheme 1. Synthetic pathway to sulfathiazole derivatives.<smiles>N#CC(C#N)N=Nc1ccc(S(=O)(=O)Nc2nccs2)cc1</smiles>

(2)<smiles>Nc1n[nH]c(N)c1N=NBr</smiles>

(3)

Scheme 2. Synthetic pathway to the aminopyrazole derivative 3 . 
It has been found that pyrazolopyrimidines ${ }^{23,24}$ and pyrazolotriazines ${ }^{25}$ have major biological and medical activities as adenine analogs, antagonists and antitumor agents. ${ }^{26-29}$ Therefore, we intend to prepare analogues of these compounds from 5-aminopyrazole derivatives (3) in high yield.

The treatment of 5-aminopyrazole derivative 3 with ethyl acetoacetate yielded a single product for which structures 4 or 5 seemed plausible (Scheme 3). ${ }^{30,31}$ The ${ }^{1} \mathrm{H}$ NMR spectrum of the reaction product did not contain a singlet signal for $\mathrm{CH}_{2}$ protons and instead two singlet signals were exposed at $\delta_{\mathrm{H}} 7.26$ and $11.46 \mathrm{ppm}$ for the pyrimidine ring $\mathrm{CH}$ and $\mathrm{NH}$ protons, confirming structure 5 rather than structure $4 .{ }^{32}$ Structure 4 was also excluded on a chemical basis. Namely, that the reaction product did not condense with an aromatic aldehyde or couple with benzene diazonium salt, which happened promptly with active methylene azinones. ${ }^{33}$

In addition, compound 3 reacted with acetylacetone to form 4-((2-amino-5,7-dimethylpyrazolo[1,5-a]pyrimi- din-3-yl)diazenyl)- $N$-(thiazol-2-yl)benzenesulfonamide (6, Scheme 3). Compound 6 was confirmed by elemental analysis and spectroscopic analysis. The IR spectrum of 6 showed absorption bands at $v_{\max } 3437,3394$, and 1560 $\mathrm{cm}^{-1}$ due to the $\mathrm{NH}_{2}$ and $\mathrm{N}=\mathrm{N}$ functions, respectively. In addition, its ${ }^{1} \mathrm{H}$ NMR spectrum showed four singlet signals at $\delta_{\mathrm{H}} 2.08,2.24,5.74$, and $7.08 \mathrm{ppm}$ assigned to two methyl, $\mathrm{NH}_{2}$, and $\mathrm{CH}$ pyrimidine protons, respectively. In addition, its mass spectrum showed the molecular ion peak at $\mathrm{m} / \mathrm{z} 428\left[\mathrm{M}^{+}\right]$, corresponding to its correct molecular formula $\left[\mathrm{C}_{17} \mathrm{H}_{16} \mathrm{~N}_{8} \mathrm{O}_{2} \mathrm{~S}_{2}\right]$. The reaction of the 5-aminopyrazole derivative 3 with arylidene malononitrile derivatives offered the pyrazolopyrimidines $\mathbf{7}$ and $\mathbf{8}$ (Scheme 3 ). Their structure was determined on the basis of their elemental and spectroscopic investigations. The mass spectra of compounds $\mathbf{7}$ and $\mathbf{8}$ showed molecular ion peaks that confirmed their expected structures. The IR spectra of both compounds showed stretching frequencies for $\mathrm{NH}_{2}$, $\mathrm{NH}$ and $\mathrm{CN}$ groups, which confirmed their proposed structures.

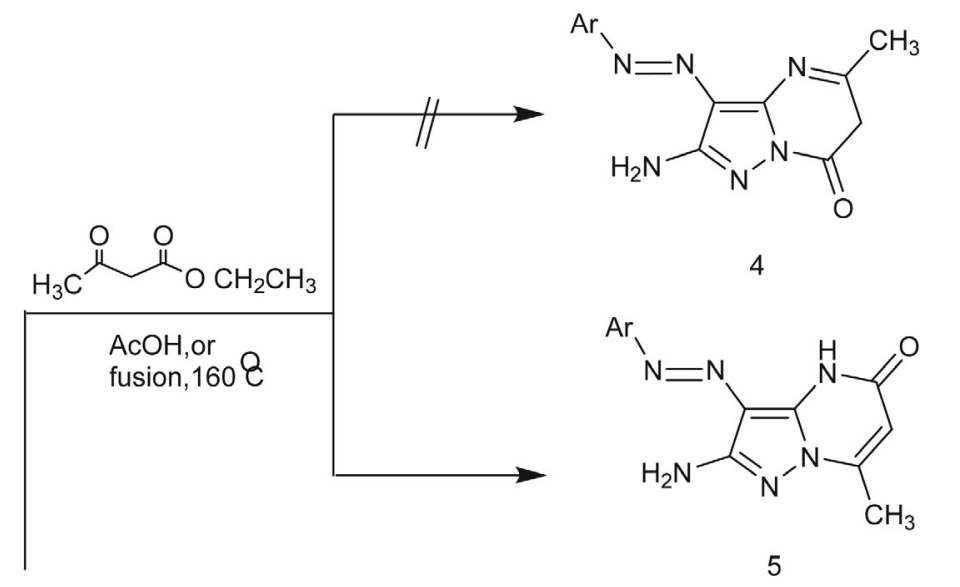<smiles>Nc1n[nH]c(N)c1N=N[Tl]</smiles>

3

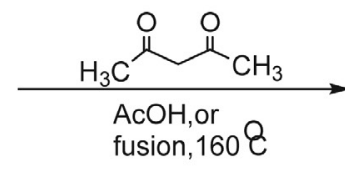

(N)

EtOH, pipridine

$\operatorname{Ar}=$

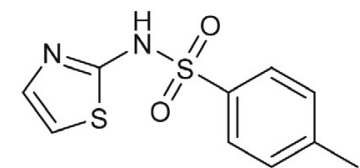<smiles>Cc1cc(C)n2nc(N)c(N=N[Al])c2n1</smiles>

6<smiles>[Y][X]Cl</smiles>

$8, \mathrm{X}=\mathrm{NO} 2$

Scheme 3. Synthetic pathway to pyrazolo[1,5-a]pyrimidine derivatives. 


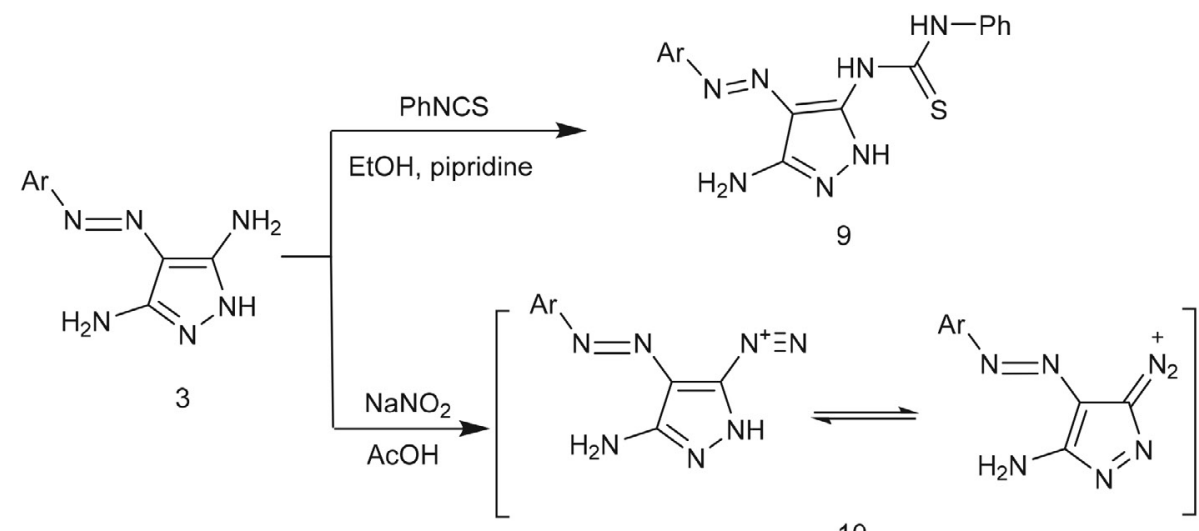

10

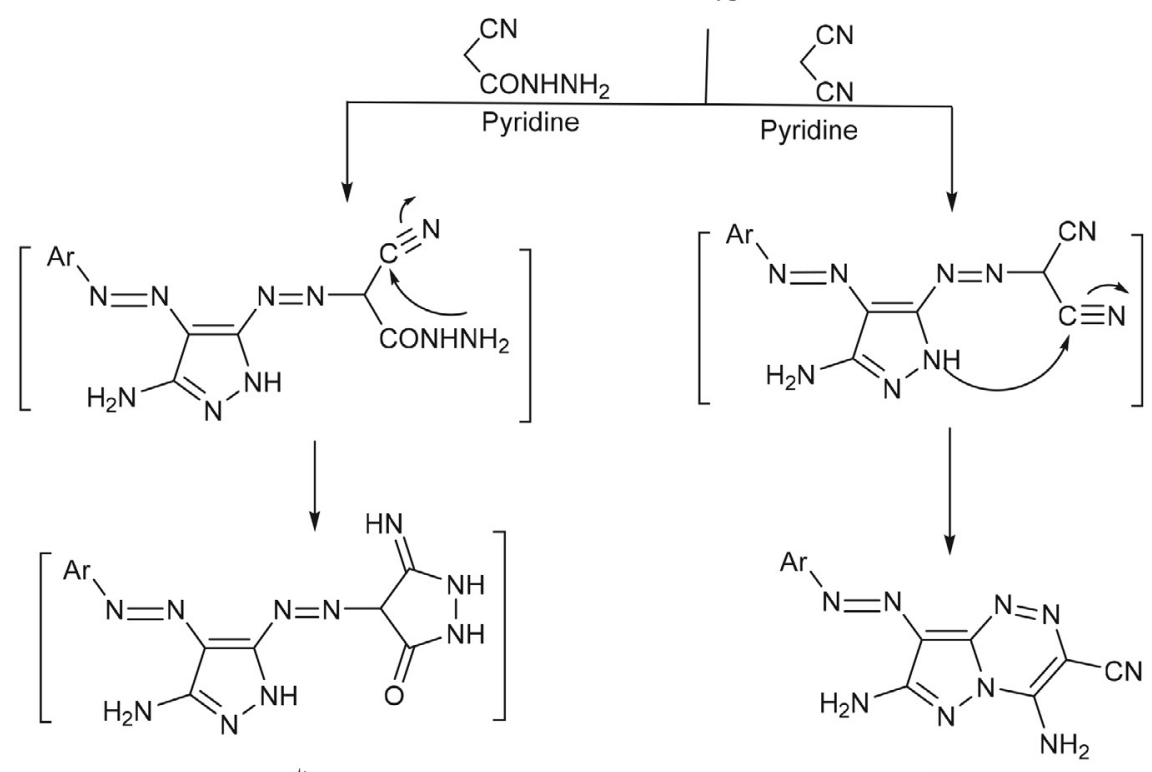

11<smiles>NC1=C(/N=N/c2[nH]nc(N)c2N=NBr)C(=O)N=N1</smiles>

$\mathrm{Ar}=$<smiles>Cc1ccc(S(=O)(=O)Nc2nccs2)cc1</smiles>

Scheme 4. Synthetic pathway to pyrazolo $[1,5-c]$ triazine and pyrazole derivatives.

The reaction of $\mathbf{3}$ with phenyl isothiocyanate yielded the pyrazolo-5-phenylthioureido derivative 9 , which was confirmed by analytical and spectroscopic data (Scheme 4). The coupling of diazonium salt $\mathbf{1 0}$ with malononitrile yields the pyrazolo[1,5-c]triazine 11, while the coupling of 10 with 2-cyanoacetohydrazide yields pyrazolone derivatives 12. The structures of $\mathbf{1 1}$ and $\mathbf{1 2}$ were confirmed based on their spectroscopic data. The IR spectrum of compound 11 showed stretching frequencies at $3447-3300 \mathrm{~cm}^{-1}$ due to $\mathrm{NH}_{2}$ and $\mathrm{NH}$ groups and a sharp peak at $2227 \mathrm{~cm}^{-1}$ due to the $\mathrm{CN}$ group. Additionally, its mass spectrum showed a molecular ion peak at $\mathrm{m} / \mathrm{z} 441$, confirming the correct molecular formula. The IR spectrum of compound $\mathbf{1 2}$ showed bands at 3417-3311, 1678 and $1565 \mathrm{~cm}^{-1}$ corresponding to two $\mathrm{NH}_{2}, \mathrm{NH}, \mathrm{CO}$ and $\mathrm{N}=\mathrm{N}$ groups, respectively. In addition, its mass spectrum showed a molecular ion peak at $\mathrm{m} / \mathrm{z} 472$, which is due to its molecular formula. Diazonium salt 10 was additionally reacted with 2 -cyano- $N$-phenylacetamide and 3,5-dimethylphenol to obtain compounds 13 and 14, respectively. The structure of compounds 13 and 14 was confirmed on the basis of elemental analysis and spectroscopic data, as already shown in the experimental part.

The significant biological and medical activity of the arylhydrazone of $\alpha$-cyanoketone as an antituberculosis agent $^{34}$ and oxidative phosphorylation inhibitor ${ }^{35}$ have 


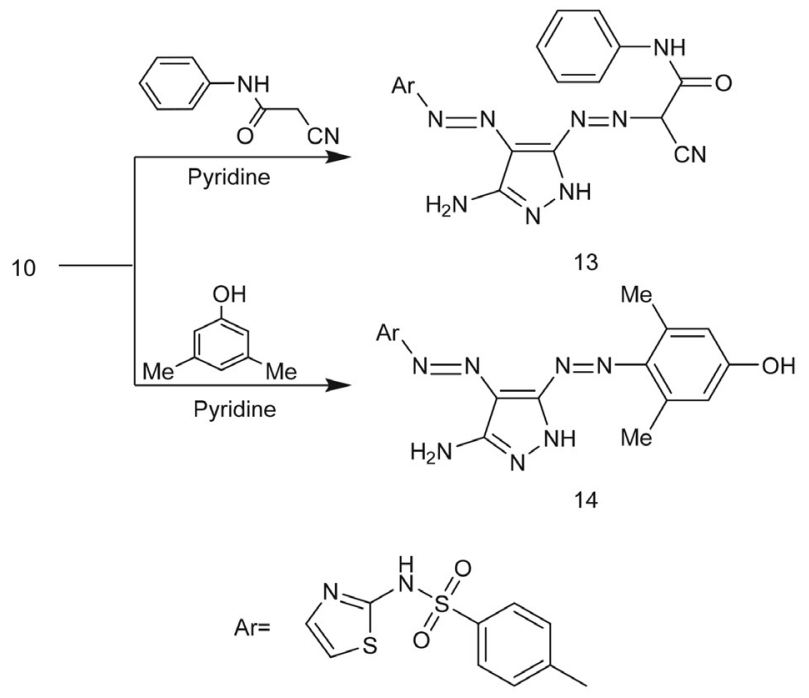

Scheme 5. Synthetic pathway to pyrazolo-4,5diazenyl derivatives.

stimulated research on this class of compounds. As part of our program, we report here on the synthesis of a cyanarylhydrazones $\mathbf{1 6}$ by treating hydrazine hydrate with $N$-methyl- $N$-(4-( $N$-(thiazol-2-yl)sulfamoyl)phenyl)carbonohydrazonoyldicyanide (15) (Scheme 6). The identity of compounds $\mathbf{1 5}$ and $\mathbf{1 6}$ was confirmed by their spectroscopic analysis.

On the other hand, the reaction of compound 2 with different nucleophiles, for example thiourea and hydroxylamine hydrochloride, enabled 4-(2-(4,6-diamino-2-thioxopyrimidin-5(2H)-ylidene)hydrazinyl)- $N$-(thiazol-2-yl) benzenesulfonamide (17) and 4-(2-(2-(3-amino-5-iminoisoxazol-4(5H)-ylidene)hydrazinyl)- $N$-(thiazol-2-yl)ben- zenesulfonamide (18), respectively. The IR spectrum of $\mathbf{1 7}$ showed the presence of two $\mathrm{NH}_{2}$ and two $\mathrm{NH}$ absorption bands at $3434-3400 \mathrm{~cm}^{-1}$, the $\mathrm{C}=\mathrm{S}$ group at $1325 \mathrm{~cm}^{-1}$ and the absence of $\mathrm{CN}$ groups. The mass spectra of compounds 17 and 18 showed a molecular ion peak that confirmed proposed structures.

\section{Antimicrobial Evaluation}

The synthesized compounds were evaluated against Bacillus subtilis and Staphylococcus Aureus as Gram-positive bacteria and against Escherichia coli and Pseudomonas Aeruginosa as Gram-negative bacteria. They were also tested for their in vitro antifungal potential against strains of Fusarium oxysporum and Candida albicans. The agar diffusion method with chloramphenicol, cephalothin and cycloheximide as reference drugs was used to determine the antibacterial and antifungal activity.

The results were recorded for each compound tested as the normal diameter of the bacterial or fungal growth inhibition zones (IZ) around the disks in mm. The MIC measurement was determined for compounds that had significant growth inhibition zones $(>14 \mathrm{~mm})$ using a twofold serial dilution method. ${ }^{36,37}$ The values for MIC and inhibition zone diameters are shown in Table 1. Most of the compounds tested showed variable inhibitory activity for the growth of the Gram-positive and Gram-negative strains of bacteria tested and against the antifungal strain. In general, most of the compounds tested showed better activity against the Gram-positive than against the Gram-negative strains.

Regarding the structure-activity relationship of sulfathiazole derivatives against Gram-positive bacteria, the re-<smiles>C=C[Al]N(C)/N=C(/C#N)C(N)=NN</smiles>

Scheme 6. Synthetic pathway to pyrimidine and isoxazole derivatives. 
Table 1. Minimum inhibiton concentration (MIC, $\mu \mathrm{g} / \mathrm{mL}$ ) and inhibition zone $(\mathrm{mm})$ of the synthesized compounds.

\begin{tabular}{|c|c|c|c|c|c|}
\hline \multirow[t]{4}{*}{ Compound No. } & \multicolumn{4}{|c|}{ MIC in $\mu \mathrm{g} / \mathrm{mL}$, and inhibition zone ( $\mathrm{mm})$} & \multirow{4}{*}{$\begin{array}{l}\text { Fungi } \\
\text { C. albicans }\end{array}$} \\
\hline & \multicolumn{4}{|c|}{ Bacteria } & \\
\hline & \multicolumn{2}{|c|}{ Gram-positive bacteria } & \multicolumn{2}{|c|}{ Gram-negative bacteria } & \\
\hline & B. subtilis & S. aureus & E. coli & P. aeruginosa & \\
\hline 2 & $3.125(40)$ & $6.25(37)$ & $100(15)$ & $50(19)$ & $3.125(36)$ \\
\hline 3 & $25(27)$ & $50(15)$ & $100(15)$ & $100(16)$ & $6.25(28)$ \\
\hline 5 & $3.125(45)$ & $6.25(38)$ & $25(25)$ & $12.5(33)$ & $3.125(40)$ \\
\hline 6 & $12.5(33)$ & $50(14)$ & $50(20)$ & $50(19)$ & $50(20)$ \\
\hline 7 & $12.5(32)$ & $50(20)$ & $100(15)$ & $100(15)$ & $100(16)$ \\
\hline 8 & $3.125(44)$ & $6.25(37)$ & $100(14)$ & $50(20)$ & $25(19)$ \\
\hline 9 & $12.5(32)$ & $50(20)$ & $100(15)$ & $100(15)$ & $6.25(30)$ \\
\hline 11 & $3.125(41)$ & $6.25(37)$ & $100(15)$ & $100(16)$ & $6.25(25)$ \\
\hline 12 & $6.25(38)$ & $6.25(30)$ & $100(14)$ & $100(15)$ & $6.25(26)$ \\
\hline 13 & $12.5(32)$ & $6.25(38)$ & $100(15)$ & $50(19)$ & $6.25(30)$ \\
\hline 14 & $6.25(37)$ & $6.25(37)$ & $100(15)$ & $100(15)$ & $12.5(32)$ \\
\hline 15 & $6.25(38)$ & $6.25(37)$ & $100(15)$ & $50(19)$ & $50(20)$ \\
\hline 16 & $6.25(38)$ & $6.25(37)$ & $100(15)$ & $50(19)$ & $100(16)$ \\
\hline 17 & $3.125(40)$ & $6.25(37)$ & $100(15)$ & $50(19)$ & $50(20)$ \\
\hline 18 & $3.125(41)$ & $6.25(38)$ & $100(15)$ & $50(19)$ & $100(16)$ \\
\hline Chloramphenicol & $3.125(44)$ & $3.125(44)$ & $6.25(37)$ & $6.25(38)$ & NT \\
\hline Cephalothin & $6.25(36)$ & $6.25(37)$ & $6.25(38)$ & $6.25(37)$ & NT \\
\hline Cycloheximide & NT & NT & NT & NT & $3.125(42)$ \\
\hline
\end{tabular}

MIC values with SEM $=0.02$ (the lowest concentration that inhibited bacterial growth). NT: Not tested.

sults showed that compounds $2,5,8,11,17$ and 18 showed a broad antibacterial profile against the organisms tested and were equivalent to chloramphenicol in inhibiting the growth of B. subtilis (MIC, $3.125 \mu \mathrm{g} / \mathrm{mL}$ ), while the activity was $50 \%$ lower than chloramphenicol against $S$. aureus. On the other hand, compounds $3,6,7,9,12,13,14,15$ and 16 showed moderate growth-inhibiting activity against Gram-positive bacteria, as shown by their MIC values $(6.25-50 \mu \mathrm{g} / \mathrm{mL})$. Of these compounds, 12, 14, 15 and $\mathbf{1 6}$ showed good growth-inhibiting activity against $B$. subtilis (MIC, $6.25 \mu \mathrm{g} / \mathrm{mL}$ ), while compounds 6, 7, 9 and 13 showed relatively good growth-inhibiting profiles against $B$. subtilis (MIC, $12.5 \mu \mathrm{g} / \mathrm{mL}$ ), accounting for about $25 \%$ of the activity of chloramphenicol and $50 \%$ of cephalothin against the similar organism. The antibacterial activity of compound $\mathbf{6}$ showed a weak growth-inhibiting effect against the tested Gram-negative bacteria (MIC, $50 \mathrm{n} \mu \mathrm{g} / \mathrm{mL}$ ). As for the activity of sulfathiazole derivative $\mathbf{2}$ against antifungal strains, the results showed their moderate to good antifungal activity.

Of the compounds studied, compounds $\mathbf{2}$ and $\mathbf{5}$ were equivalent to cycloheximide in inhibiting the growth of $C$. albicans (MIC $3.125 \mu \mathrm{g} / \mathrm{mL}$ ). In contrast, compounds 3, 9, 11, 12 and 13 showed 50\% lower activity than cycloheximide in inhibiting the growth of C. albicans (MIC $6.25 \mu \mathrm{g} /$ $\mathrm{mL}$ ), while the activity of compound $\mathbf{1 4}$ was $25 \%$ lower than that of cycloheximide against C. albicans (MIC $12.5 \mu \mathrm{g}$ / $\mathrm{mL}$ ). In general, the tested compounds were more active against Gram-positive bacteria than Gram-negative bacteria, and it could be argued that the antimicrobial activity of the compounds is related to the cell wall structure of the bacteria. Indeed, the cell wall is essential for the survival of bacteria and some antibiotics are able to kill bacteria by inhibiting a step in the synthesis of peptidoglycan. Gram-positive bacteria have a thick cell wall that contains many layers of peptidoglycan and teichoic acids, but in contrast, Gram-negative bacteria have a relatively thin cell wall that consists of a few layers of peptidoglycan and is surrounded by a second lipid membrane that contains lipopolysaccharides and lipoproteins. These differences in cell wall structure can lead to differences in antibacterial susceptibility, and some antibiotics can only kill Gram-positive bacteria and are inactive against Gram-negative pathogens. ${ }^{38}$

By comparing the antimicrobial activity of the compounds reported in this study with their structures, the following structure-activity relationships (SAR) were postulated:

- The presence of a basic sulfathiazole skeleton is necessary for the broad spectrum of antimicrobial activity.

- The introduction of electron-withdrawing groups, such as $\mathrm{CN}$ or $\mathrm{NO}_{2}$, increases the antimicrobial activity.

- Compounds 2, 8, 11, 17 and 18 showed the highest antimicrobial activity, while the other compounds showed weak to moderate antimicrobial activity.

\section{Conclusion}

The present study reports on the efficacy of pyrazolo[1,5-a]pyrimidine and pyrazolo[1,5-c]triazine derivatives containing a sulfathiazole unit. The simple synthesis strategy and the very good yields of the compounds produced are the main advantages of the protocol presented. 
The newly synthesized compounds showed moderate to good antibacterial and antifungal activities.

\section{Acknowledgements}

The authors are grateful to Pharmacology Department, Faculty of Pharmacy, Mansoura University, for the screening of the biological activity. The authors declare that there is no conflict of interest.

\section{References}

1. J. R. Anacona, J. L. Rodriguez, J. Camus, Spectrochim Acta Part A, 2014, 129, 96-102. DOI:10.1016/j.saa.2014.03.019

2. S. Ostovar, D. Rodriguez-Padron, F. Saberi, A. M. Balu, R. Luque, Catalysts, 2018, 9, 348. DOI:10.3390/catal9040348

3. H. Nikoofard, M. Sargolzaei, F. Faridbod, Acta Chim. Slov. 2017, 64, 842-848. DOI:10.17344/acsi.2017.3357

4. J. Elguero, P. Goya, N. Jagerovic, A. M .S. Silva, in Targets in Heterocyclic Systems: Chemistry and Properties, O.A. Attanasi, D. Spinelli (Eds.), sixth ed., Societ a Chimica Italiana, Roma, 2006, pp. 52-98.

5. G. Szabo, J. Fischer, A. Kis-Varga, K. Gyires, J. Med. Chem. 2008, 51, 142-147. DOI:10.1021/jm070821f

6. M. F. El-Shehry, E. M. El Telbani, M. I. Hegab, Acta Chim. Slov., 2018, 65, 401-406. DOI:10.17344/acsi.2017.4144

7. H. Beyzaei, Z. Motraghi, R. Aryan, M. M. Zahedi, A. Samzadeh-Kermani, Acta Chim. Slov., 2017, 64, 911-918.

DOI:10.17344/acsi.2017.3609

8. A. Tanitame, Y. Oyamada, K. Ofuji, H. Terauchi, M. Kawasaki, M. Wachi, J. Yamagishi, Bioorg. Med. Chem. Lett. 2005, 15, 4299-4303. DOI:10.1016/j.bmcl.2005.06.103

9. A. Tanitame, Y. Oyamada, K. Ofuji, M. Fujimoto, K. Suzuki, T. Ueda, H. Terauchi, M. Kawasaki, K. Nagai, M. Wachi, J. Yamagishi, Bioorg. Med. Chem. 2004, 12, 5515-5524. DOI:10.1016/j.bmc.2004.08.010

10. N. Cho, M. Kamaura, T. Yogo, H. Imoto, PCT Int. Appl. (2009). WO 2009139340.

11. K. Dugi, M. Mark, F. Himmelsbach, PCT Int. Appl. (2009). WO 2009022009.

12. Y. Momose, T. Maekawa, H. Odaka, H. Kimura, PCT Int. Appl. (2001). WO 2001038325.

13. S. M. Rida, M. N. S. Saudi, A. M. Youssef, M. A. Halim, Lett. Org. Chem. 2009, 6, 282-288. DOI:10.2174/157017809788489909

14. M. G. Brasca, C. Albanese, R. Amici, D. Ballinari, L. Corti, V. Croci, D. Fancelli, F. Fiorentini, M. Nesi, P. Orsini, F. Orzi, W. Pastori, E. Perrone, E. Pesenti, P. Pevarello, F. Riccardi-Sirtori, F. Roletto, P. Roussel, M. Varasi, A. Vulpetti, C. Mercurio, Chem. Med. Chem. 2007, 2, 841-852.

DOI: $10.1002 / \mathrm{cmdc} .200600302$

15. P. Pevarello, D. Fancelli, A. Vulpetti, R. Amici, M. Villa, V. Pittal_a, P. Vianello, A. Cameron, M. Ciomei, C. Mercurio, J. R. Bischoff, F. Roletto, M. Varasi, M. G. Brasca, Bioorg. Med. Chem. Lett. 2006, 16, 1084-1090.

DOI:10.1016/j.bmcl.2005.10.071
16. A. H. Abadi, A. A. H. Eissa, G. S. Hassan, Chem. Pharm. Bull. 2003, 51, 838-844. DOI:10.1248/cpb.51.838

17. S. A. Margolis, G. Lenaz, H. Baum, Arch. Biochem. Biophys. 1967, 118, 224-230. DOI:10.1016/0003-9861(67)90301-3

18. H. M. Refat, A. A. Fadda, Eur. J. Med. Chem. 2013, 70, 419426. DOI:10.1016/j.ejmech.2013.09.003

19. A. A. Fadda, K. S. Mohamed, H. M. Refat, E. E. El-Bialy, Heterocycles, 2015, 91, 134-148. DOI:10.3987/COM-14-13129

20. H. E. Elsherbiny, A. A. Fadda, J. Heterocycl. Chem. 2018, 55, 2251-2260. DOI:10.1002/jhet.3276

21. H. E. Elsherbiny, A. A. Fadda, Acta Chim. Slov. 2018, 65, 853864. DOI:10.17344/acsi.2018.4506

22. S. M. Khaled, H. E. Elsherbiny, Heterocycles, 2018, 96, 18971909. DOI:10.3987/COM-18-13969

23. G. B. Elion, S. Callahan, H. Nathan, S. Bieber, R. W. Rundles, G. H. Hitchings, Biochem. Pharmacol. 1963, 12, 85-93. DOI:10.1016/0006-2952(63)90012-1

24. N. Polish, M. Nesterkina, N. Marintsova, A. Karkhut, I. Kravchenko, V. Novikov, A. Khairulin, Acta Chim. Slov. 2020, 67, 934-939. DOI:10.17344/acsi.2020.5938

25. T. Novinson, R. Hanson, M. K. Dimmitt, L. N. Simon, R. K. Robins, D. E. O'Brien, J. Med. Chem. 1974, 17, 645-648. DOI:10.1021/jm00252a016

26. I. Ito, Japan Patent, 7030101. 1970 [Chem. Abstr. 1971, 74, 22827].

27. S. A. El-Hadidya, S. Abu-Melhab, Acta Chim. Slov. 2020, 67, 167-178. DOI:10.17344/acsi.2019.5308

28. M. Abdel-Motaal, A. L. Alanzy, M. Asem, Acta Chim. Slov. 2020, 67, 560-569. DOI:10.17344/acsi.2019.5571

29. R. R. Varma, J. G. Pandya, F. U. Vaidya, C. Pathak, B. S. Bhatt, M. N. Patel, Acta Chim. Slov. 2020, 67, 957-969.

DOI:10.17344/acsi.2020.6017

30. M. H. Elnagdi, E. M. Kandeel, K. U. Sadek, Z. Naturforsch B Chem. Sci. 1979, 34, 275- 279.

DOI:10.1515/znb-1979-0227

31. M. H. Elnagdi, E. M. Kandeel, M. R. H. Elmoghayar, Z. Naturforsch B Chem. Sci. 1977, 32, 307-310.

DOI:10.1515/znb-1977-0315

32. M. H. Elnagdi, E. M. Kandeel, E. M. Zayed, Z. E. Kandil, J. Heterocycl. Chem. 1977, 14, 155-158.

DOI:10.1002/jhet.5570140132

33. A. A. Fadda, E. M. Afsah, S. Bondock, M. M. Hammouda, Tetrahedron, 2012, 68, 2081-2091.

DOI:10.1016/j.tet.2011.12.016

34. T. Zsolnai, Biochem. Pharmacol. 1965, 14, 1325-1362. DOI:10.1016/0006-2952(65)90119-X

35. J. F. Ferris, in Biological junction and formation of cyano group in "The Chemistry of Cyano Group", Z. Rappaport (ed.), Interscience, New York; 1970, Chapt. 12, p 735.

36. A. U. Rahman, M. I. Choudhary, W. J. Thomsen, Bioassay Techniques for drug development, Harwood Academic Publishers, the Netherlands; 2001, p 16.

37. A. A. Fadda, E. M. Afsah, R. S. Awad, Eur. J. Med. Chem. 2013, 60, 421-430. DOI:10.1016/j.ejmech.2012.11.017

38. H. Abuo-Melha, A. A. Fadda, J. Spectrochim. Acta Part A. 2012, 89, 123-128. DOI:10.1016/j.saa.2011.12.054 


\section{Povzetek}

Avtorji poročajo o pripravi večjega števila derivatov pirazolo[1,5-a]pirimidina z reakcijo 4-((3,5-diamino- $1 H$-pirazol-4-il)-diazenil)- $\mathrm{N}$-(tiazol-2-il))-benzensulfonamida z nekaterimi bifunkcionalnimi nukleofili, kot so etil acetoacetat, acetilaceton ali derivati arilidenmalonononitrila. Strukture novo sintetiziranih spojin so določili na podlagi njihovih IR, ${ }^{1} \mathrm{H}$ in ${ }^{13} \mathrm{C}$ NMR ter masnih spektroskopskih podatkov. Večina pripravljenih spojin je pokazala dobro protibakterijsko in protiglivično delovanje. 